American Journal of Applied Sciences 8 (6): 610-616, 2011

ISSN 1546-9239

(C) 2011 Science Publications

\title{
Static and Dynamic Performance Improvement of Conventional Computer Numerical Control Machine Tool Bed with Hybrid Welded Steel
}

\author{
${ }^{1}$ S.S. Abuthakeer, ${ }^{1}$ P.V. Mohanram and ${ }^{2}$ G. Mohankumar \\ ${ }^{1}$ Department of Mechanical Engineering, PSG College of Technology, India \\ ${ }^{2}$ Park College of Engineering and Technology, India
}

\begin{abstract}
Problem statement: The advancements in machine tools to maximize the production by increasing spindle speeds have caused vibration in machine tools. The two functional requirements of machine tool bed for machine tools are high structural stiffness and high damping, which cannot be satisfied simultaneously if conventional metallic materials such as cast iron are employed. Hence there is a need to replace cast iron with alternate materials. Approach: The objective of this study is to improve the stiffness, natural frequency and damping capability of machine tool bed using a composite material containing welded steel and polymer concrete. Welded steel material has high stiffness but low damping and polymer concrete has high damping but low stiffness. So in this study, a machine tool bed made of sandwich structures of welded steel and polymer concrete is designed and manufactured. Modal and static analyses were conducted numerically and experimentally to determine the modal frequencies, damping ratio, deformation and strain. Results: The results at first mode showed that the natural frequency improved by $24.7 \%$ and damping ratio was 2.7 times higher than cast iron. The comparison of strain and deformation also showed significant improvement. Conclusion: This study proposed a hybrid welded steel bed as a replacement for cast iron as a machine tool bed material and the results showed that the static and dynamic characteristics were superior to cast iron.
\end{abstract}

Key words: CNC machine tool, cast iron bed, hybrid welded bed, static performance, dynamic performance, functional requirements, sandwich structures, conventional materials dynamic performances, various points, modal analysis, material properties

\section{INTRODUCTION}

Machine tools play an important role in manufacturing industry. The productivity, precision and durability of machine tools have increased considerably in the past few decades, with an accompanying decrease in their metal content. This significantly increases the requirements on the operational and technological properties of the materials employed (Shevchuk, 2008). Surface roughness is a major consideration in modern Computer Numerical Control (CNC) machine (Tian-Syung Lan, 2010). It is desirable that the negative effects such as vibration and noise in the machine tools used today be brought to a minimum level. The desirable properties of machine tool include high static stiffness for bending and torsion, good dynamic characteristics, good dimensional stability, low coefficient of expansion, low cost and low material requirements ( Rahman et al., 2001). Materials used in manufacturing machine tools, especially when viewed in terms of their mechanical characteristics, have a great importance in comparison to other construction materials and this will continue in the future. But when viewed in terms of properties such as chemical resistance, ease of production, workability, stiffness and damping, conventional materials such as cast iron are least preferred (Kalpakjian and Schmid, 2009; Acherkan et al., 2000) Cast iron, a traditional material used in the manufacture of structural components of a machine tool possesses these characteristics to an acceptable level. But its inherent disadvantages include high cost, poor torsional rigidity due to thin walls; difficulty in producing the finished product etc. have lead the researchers to look for alternative materials either to supplement or to completely replace cast iron for the fabrication of machine tool structures (Rahman et al., 1990). Many materials have been found to have the ability to replace the conventional cast iron such as mild steel weldments, granite, ceramics, concrete, ferrocement, polymers, epoxy granite and composites. The two most important functional requirements for a machine tool are high stiffness and damping which improves the static and dynamic performances of the machine tool (Jung Do Suh and Dai Gil Lee, 2008). 
Several researches have been done to find a suitable replacement to cast iron. Researchers suggested ferrocement as a replacement to cast iron. The bed of a centre lathe made of traditional cast iron was replaced by ferrocement and tested for its static and dynamic properties. Test results indicated that the machine with ferrocement bed provides significantly higher damping and natural frequencies (Rahman et al., 1993). Attempts were made to identify the optimal composition of epoxy concrete and fabricate a ultra precision machine tool bed made of epoxy concrete (Hyun Surk Kim et al., 1995).

A machine tool bed made of Steel Fiber reinforced Polymer Concrete (SFPC) was fabricated and analyzed to estimate their static and dynamic properties. It was found that SFPC is much more superior to cast iron in dynamic and thermal properties (Xu Ping and Yu Yinghua, 2008). The vertical and horizontal frames of a high speed CNC milling machine were designed and manufactured with sandwich composite structures that are adhesively bonded to welded steel structures. The hybrid structure had a mass reduction of $30 \%$ as compared to conventional steel structures. The damping factor also was increased by 1.5 5.7 times than those of the conventional structures (Suh et al., 2002). Damping properties of polymer concrete and cast iron were measured and compared. It was found that the polymer concrete bed has a damping ratio higher than that of gray cast iron (Corte's and Castillo, 2007). The feasibility of polymer concrete in the manufacture of machine tool beds was investigated and it was found that damping ratio of polymer concrete was approximately 4 to 7 times higher than that of cast iron (Sezan Orak, 2000). In this study a hybrid welded steel bed is designed and fabricated with polymer concrete base to replace the conventional cast iron bed as the best way to obtain both high stiffness and damping is to employ sandwich structures made of high stiffness and high damping materials. The bed made of cast iron has inherent disadvantages such as low stiffness, pollution causing foundry materials and difficulty in producing the finished product. The hybrid bed consists of welded steel which has high stiffness and low weight and polymer concrete which has high damping capacity. The static and dynamic performances of both the cast iron and hybrid bed are analyzed experimentally and numerically. The results are compared and the experiments are validated using numerical results.

The hybrid bed showed improved static and dynamic performances when compared with cast iron.

\section{MATERIALS AND METHODS}

In this study, a machine tool bed made of sandwich structures of welded steel and polymer concrete is modeled, manufactured and analyzed to suggest it as a suitable replacement for conventional cast iron.

Experimental analysis of cast iron bed: The cast iron bed is tested experimentally using LabVIEW 8.2 and numerical tests are conducted using ANSYS 12.0 and the results are compared to validate the experiments.

Experimental modal analysis of cast iron bed: Modal analysis is the study of the dynamic properties of a structure under vibration excitation. With modal analysis, engineers can extract the modal parameters (dynamic properties) of a structure. The modal parameters, including natural frequency, damping ratio and mode shape, are the fundamental elements that describe the movement and response of a structure to ambient excitation as well as forced excitation (Syath Abuthakeer et al., 2010). The experimental setup consisted of an impact hammer, a charge accelerometer, signal conditioner and data acquisition as shown in Fig. 1. This experimental setup was used to find the modal characteristics of the cast iron bed. The excitation by impact was given to bed by impact hammer and thus the response was obtained experimentally. The frequency versus acceleration curve was used to determine modal parameters i.e., natural frequency and damping factor. Natural frequencies of cast iron bed are determined from Fig. 2 as shown in Table 2. The damping ratios are calculated for different modal frequencies using the half power bandwidth method (Singeresu S. Rao, 2009). The damping ratio is calculated by using the Eq. 1 .

$\zeta=\left(f_{2}-f_{1}\right) /\left(2 * f_{n}\right)$

Where:

$\left(\mathrm{f}_{2}-\mathrm{f}_{1}\right)=$
$\mathrm{f}_{\mathrm{n}}=$

Represent the half power band width and the corresponding natural frequency, respectively.

Experimental static analysis of cast iron bed: The objective of analysis of static behavior is to determine the strain of lathe bed. The beds are assumed to be simply supported and loaded using hydraulic jack. Strain gauges are placed on right and left side on the bed near the area where load is applied.

The load application was made uniform by using a rectangular metallic bar. The loads are detected by the proving ring's dial indicator and noted. A strain indicator to which the strain gauges are connected indicates the strain in microns. Load is increased in steps of $140 \mathrm{~N}$ and strain readings are noted. The experimental setup is as shown in Fig. 3. The strain is measured at various points and the readings are noted. The strain values are tabulated in Table 5. 


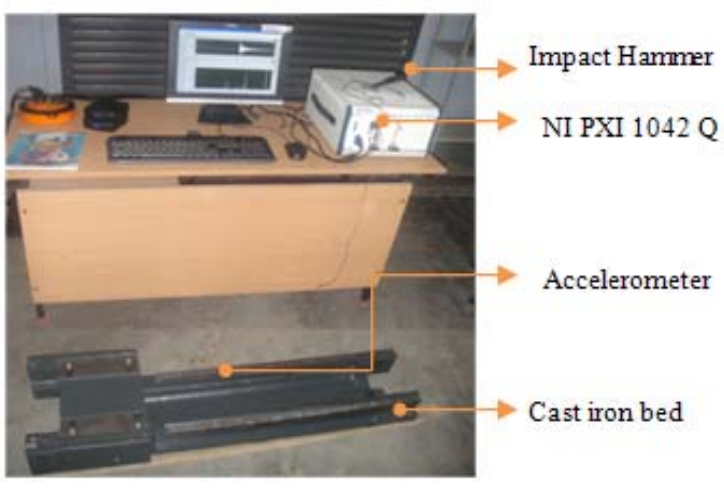

Fig. 1: Experimental setup for modal analysis of cast iron bed

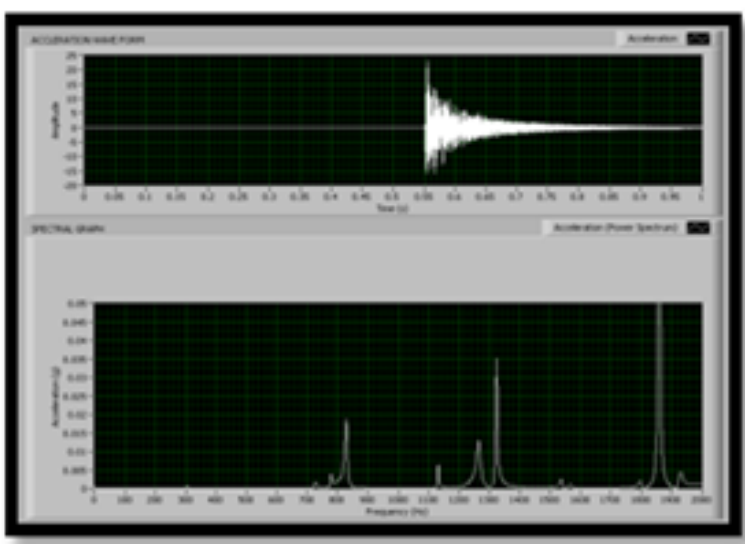

Fig. 2: Response of cast iron bed

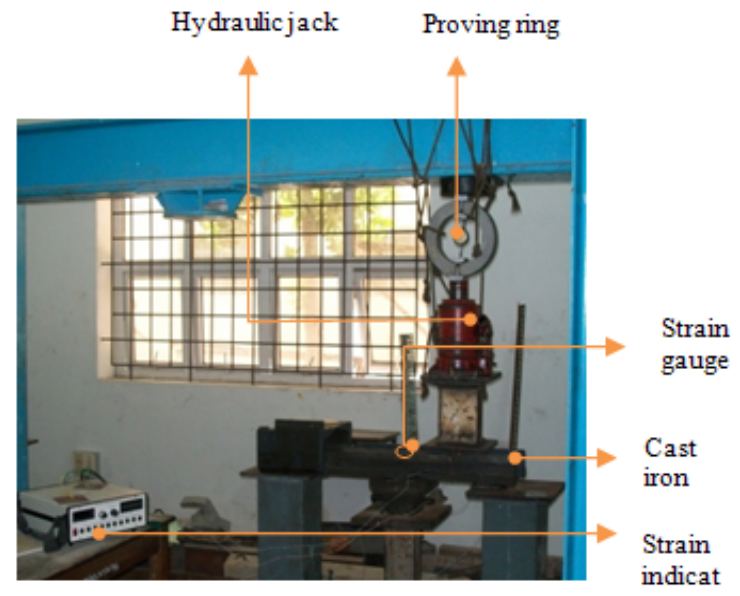

Fig. 3: Experimental setup for static analysis of cast iron bed

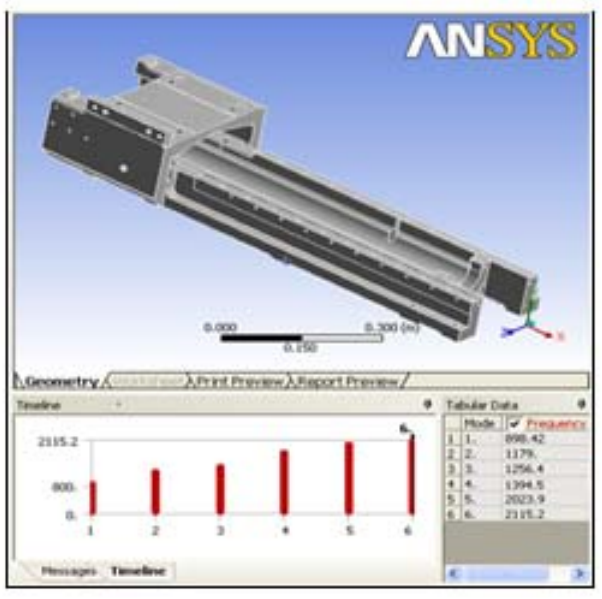

Fig. 4: Numerical modal analysis of cast iron bed

Numerical analysis of cast iron bed: The modeling of the cast iron bed is done in Pro-E Wildfire 5.0. Numerical analysis is performed in ANSYS 12.0 software.

Numerical modal analysis of cast iron bed: Modal analysis is used to determine the natural frequencies, mode shapes of the cast iron bed. Applying the conditions specified below, the natural frequencies of the bed can be obtained. Material properties are as in Table 1. The modal analysis results obtained in ANSYS is as shown in Fig. 4. Natural frequencies of the cast iron bed and comparison with experimental values and the error percentage are shown in Table 5.

Numerical static analysis of cast iron bed: The model after meshing is subjected to various boundary conditions and the loads are specified as shown in Table 5. The machine tool bed is fixed at ten places by bolted supports so they are modeled as fixed supports. The static test is conducted by gradually increasing the loads and measuring strain at various points on the lathe bed. The comparison of numerical and experimental tests results are shown in Table 5 and are found to be closer to each other. The strain plot and the total deformation plot for $140 \mathrm{~N}$ are shown in Fig. 5.

Experimental analysis of hybrid welded steel bed: The hybrid welded steel bed is made of mild steel plates of thickness $5 \mathrm{~mm}$ and welding them together. Polymer concrete is used to strengthen the bed's damping capacity. 

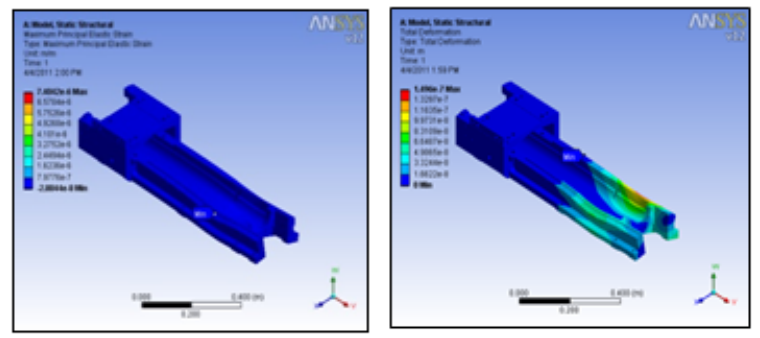

Fig. 5: Total deformation and strain plot of $140 \mathrm{~N}$ of cast iron bed

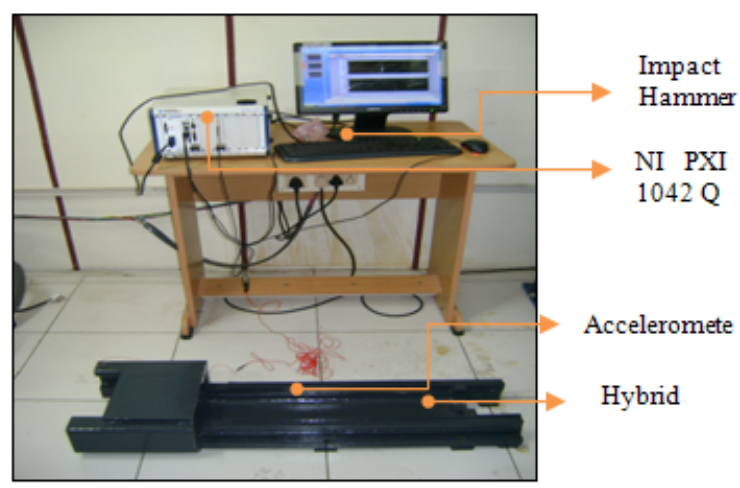

Fig. 6: Experimental setup for modal analysis of hybrid welded steel bed

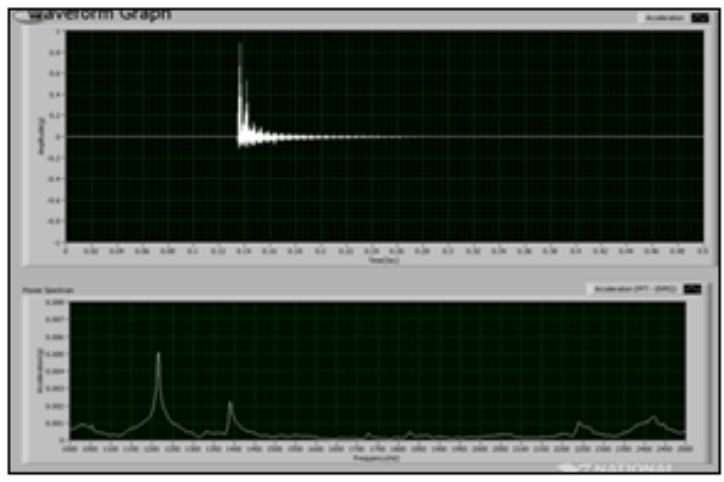

Fig. 7: Response of hybrid welded steel bed

Experimental modal analysis: The experimental modal tests are used to determine the modal frequencies of the machine tool bed. This will help to identify if the natural frequency coincide with operating frequency which in turn will help to control vibration. The setup is shown in Fig. 6. The results are shown in Fig. 7.

The test procedure is similar to that conducted on cast iron bed.

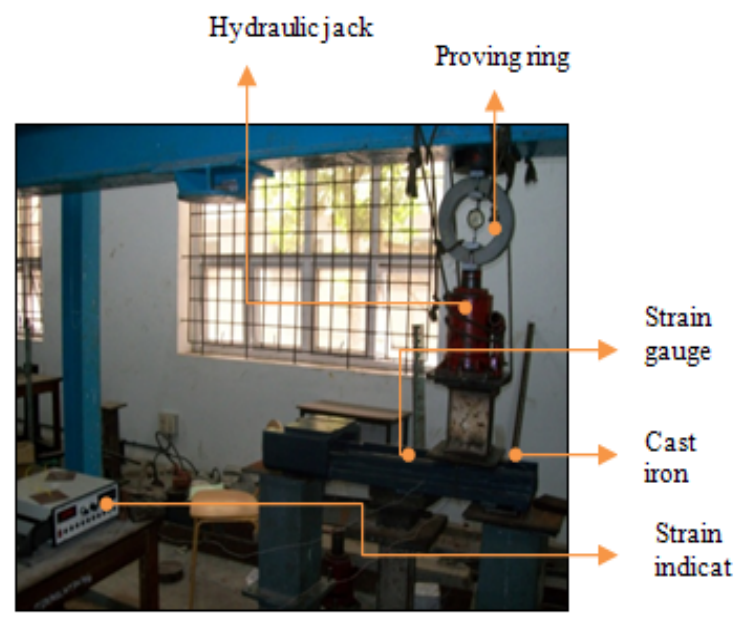

Fig. 8: Experimental setup for static analysis of hybrid welded steel bed

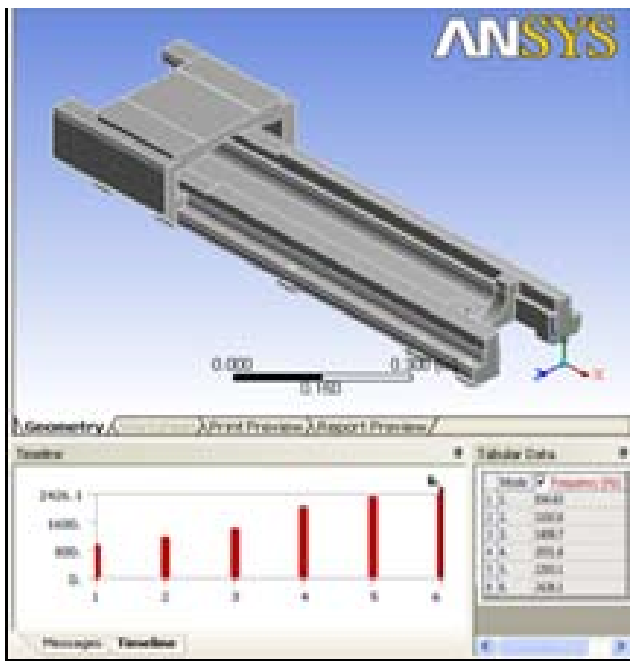

Fig. 9: Numerical modal analysis of hybrid welded steel bed

Experimental static analysis: The static analysis is used to measure the strain characteristics when the bed is subjected to loading. Strain gauges are placed on the lathe bed both at the left and right end of the lathe bed. The loads are detected by the proving ring's dial indicator and noted. A strain indicator to which the strain gauges are connected indicates the strain in microns. The loading procedure is similar to the one followed for cast iron bed and the experimental setup is as shown in Fig. 8. The results are tabulated in Table 5. 
Am. J. Applied Sci., 8 (6): 508-519, 2011
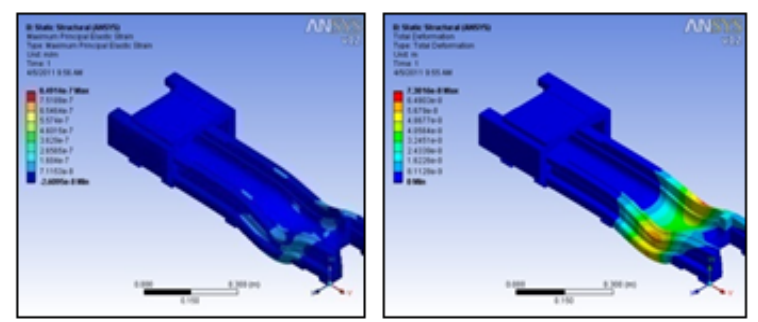

Fig. 10: Total strain and deformation plot of $140 \mathrm{~N}$ for hybrid welded steel bed

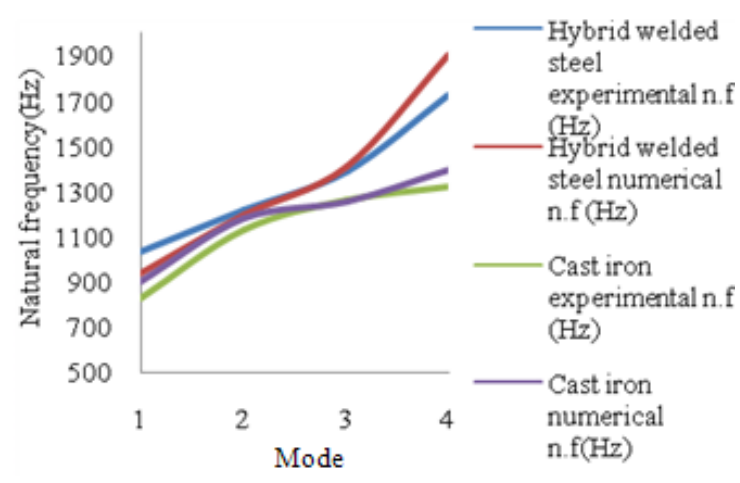

Fig. 11: Comparison of modal frequencies

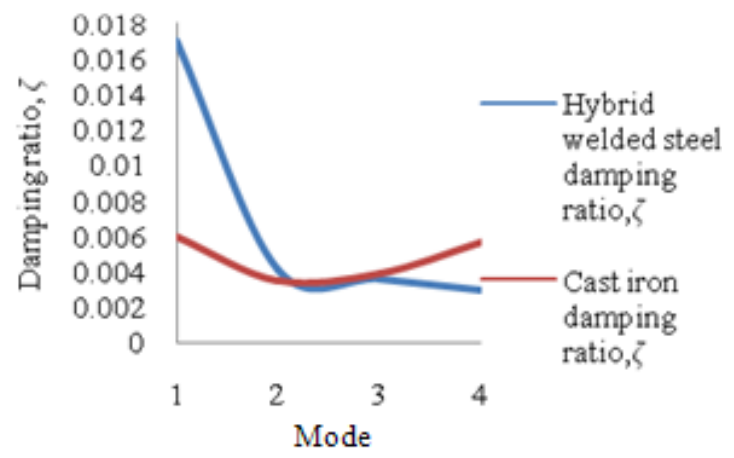

Fig. 12: Comparison of damping ratios

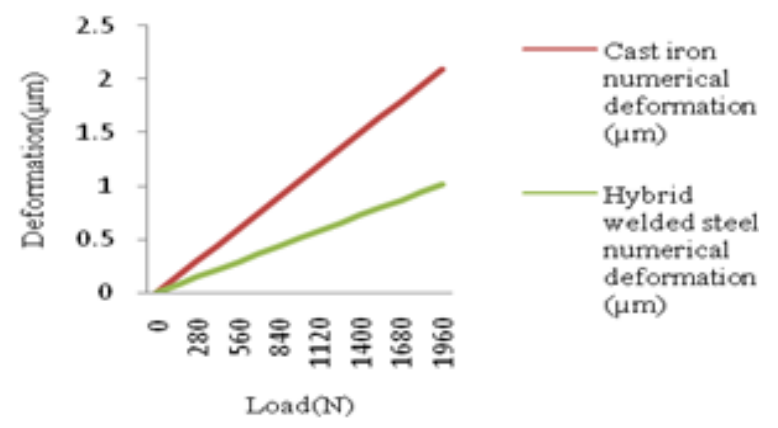

Fig. 13: Comparison of numerical deformation

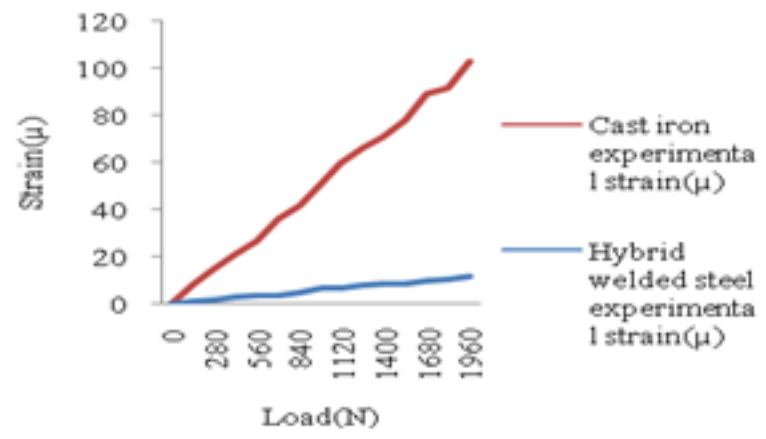

Fig. 14: Comparison of experimental strain

Table 1: Material properties of cast iron

\begin{tabular}{|c|c|c|c|c|}
\hline \multicolumn{3}{|c|}{ Properties } & \multicolumn{2}{|c|}{ Cast iron } \\
\hline \multicolumn{3}{|c|}{ Density } & \multicolumn{2}{|c|}{$7200 \mathrm{~kg} \mathrm{~m}^{3^{-1}}$} \\
\hline \multicolumn{3}{|c|}{ Young's modulus } & \multicolumn{2}{|c|}{$2.1 \mathrm{e}+11 \mathrm{~Pa}$} \\
\hline \multicolumn{3}{|c|}{ Specific Heat } & \multicolumn{2}{|c|}{$\begin{array}{l}2.1 \mathrm{e}+11 \mathrm{~Pa} \\
434 \mathrm{~J} \mathrm{~kg}^{-1}{ }^{\circ} \mathrm{C}\end{array}$} \\
\hline \multicolumn{3}{|c|}{ Thermal Conductivity } & \multicolumn{2}{|c|}{$\begin{array}{l}434 \mathrm{~J} \mathrm{~kg}^{-1}{ }^{\circ} \mathrm{C} \\
60.5 \mathrm{~W} \mathrm{~m}^{-1}{ }^{\circ} \mathrm{C}\end{array}$} \\
\hline \multicolumn{3}{|c|}{ Poisson's ratio } & \multicolumn{2}{|c|}{0.3} \\
\hline \multicolumn{5}{|c|}{ Table 2: Comparison of natural frequencies of the cast iron bed } \\
\hline Mode & $\begin{array}{l}\text { Experimental } \\
\text { natural } \\
\text { frequency }(\mathrm{Hz})\end{array}$ & $\begin{array}{l}\text { Numerical } \\
\text { natural } \\
\text { frequency }(\mathrm{Hz})\end{array}$ & $\begin{array}{l}\text { Error } \\
\text { percentage }\end{array}$ & $\begin{array}{l}\text { Damping } \\
\text { ratio, } \zeta\end{array}$ \\
\hline 1 & 830 & 898.42 & 8.24 & 0.0060 \\
\hline 2 & 1130 & 1179 & 4.33 & 0.0035 \\
\hline 3 & 1260 & 1256.4 & -0.28 & 0.0039 \\
\hline 4 & 1320 & 1394.5 & 5.64 & 0.0057 \\
\hline
\end{tabular}

Table 3: Material properties of welded steel and polymer concrete

\begin{tabular}{lll}
\hline Properties & Steel & Polymer concrete \\
\hline Density & $7850 \mathrm{~kg} \mathrm{~m}^{3-1}$ & $2300 \mathrm{~kg} \mathrm{~m}^{3-1}$ \\
Young's modulus & $2.1 \mathrm{e}+11 \mathrm{~Pa}$ & $3 \mathrm{e}+10 \mathrm{~Pa}$ \\
Specific Heat & $434 \mathrm{~J} \mathrm{~kg}^{-1}{ }^{\circ} \mathrm{C}$ & $780 \mathrm{~J} \mathrm{~kg}^{-1}{ }^{\circ} \mathrm{C}$ \\
Thermal Conductivity & $60.5 \mathrm{~W} \mathrm{~m}^{-1}{ }^{\circ} \mathrm{C}$ & $0.72 \mathrm{~W} \mathrm{~m}^{-1}{ }^{\circ} \mathrm{C}$ \\
Poisson's ratio & 0.3 & 0.18 \\
\hline
\end{tabular}

Table 4: Comparison of natural frequencies of the hybrid welded steel bed

\begin{tabular}{lllll}
\hline & $\begin{array}{l}\text { Experimenta } \\
\text { natural } \\
\text { frequency }(\mathrm{Hz})\end{array}$ & $\begin{array}{l}\text { lnumerical } \\
\text { natural } \\
\text { frequency }(\mathrm{Hz})\end{array}$ & $\begin{array}{l}\text { Error } \\
\text { percentage }\end{array}$ & $\begin{array}{l}\text { Damping } \\
\text { ratio, } \zeta\end{array}$ \\
\hline 1 & 1030 & 934.63 & -9.259 & 0.017 \\
2 & 1215 & 1192.6 & -1.843 & 0.0041 \\
3 & 1390 & 1409.7 & 1.417 & 0.0036 \\
4 & 1725 & 1905.6 & 10.46 & 0.0029 \\
\hline
\end{tabular}

Numerical analysis of hybrid welded steel bed:

Numerical tests are used to validate the experimental results. The hybrid bed is designed in Pro-E Wildfire 5.0 and analyzed in ANSYS software. The material properties used for both the static and modal analysis are shown in Table 3.

Numerical tests are used to validate the experimental results. The hybrid bed is designed in ProE Wildfire 5.0 and analyzed in ANSYS software. The material properties used for both the static and modal analysis are shown in Table 3. 
Am. J. Applied Sci., 8 (6): 508-519, 2011

Table 5: Experimental and numerical results of CNC machine tool beds

\begin{tabular}{|c|c|c|c|c|c|c|c|c|}
\hline \multirow[b]{3}{*}{ Load $(\mathrm{N})$} & \multicolumn{4}{|c|}{ Cast iron bed } & \multicolumn{4}{|c|}{ Hybrid welded steel bed } \\
\hline & \multicolumn{2}{|c|}{ Experimental } & \multicolumn{2}{|l|}{ Numerical } & \multirow{2}{*}{$\begin{array}{l}\text { Experimental } \\
--------- \\
\text { Strain } \\
\text { right }(\mu)\end{array}$} & \multicolumn{3}{|c|}{ Numerical } \\
\hline & $\begin{array}{l}\text { Strain } \\
\text { Right }(\mu)\end{array}$ & $\begin{array}{l}\text { Strain } \\
\text { left }(\mu)\end{array}$ & Strain $(\mu)$ & $\begin{array}{l}\text { Deformation } \\
(\mu \mathrm{m})\end{array}$ & & $\begin{array}{l}\text { Strain } \\
\text { left }(\mu)\end{array}$ & $\begin{array}{l}\text { Strain } \\
(\mu \mathrm{m})\end{array}$ & $\begin{array}{l}\text { Deformation } \\
(\mu \mathrm{m})\end{array}$ \\
\hline 0 & 0 & 0 & 0 & 0 & 0 & 0 & 0 & 0 \\
\hline 140 & 7 & 8 & 7.4042 & 0.1496 & 1 & 1 & 0.84914 & 0.073016 \\
\hline 280 & 14 & 15 & 14.808 & 0.29919 & 2 & 2 & 0.16983 & 0.14603 \\
\hline 420 & 22 & 21 & 22.212 & 0.44879 & 3 & 3 & 2.5474 & 0.21905 \\
\hline 560 & 27 & 27 & 29.617 & 0.59839 & 3 & 4 & 3.3966 & 0.29206 \\
\hline 700 & 35 & 36 & 37.021 & 0.74798 & 4 & 4 & 4.2457 & 0.36508 \\
\hline 840 & 41 & 42 & 44.425 & 0.89758 & 5 & 5 & 5.0948 & 0.43809 \\
\hline 980 & 53 & 51 & 51.829 & 1.0472 & 6 & 7 & 5.944 & 0.51111 \\
\hline 1120 & 61 & 60 & 59.233 & 1.1986 & 7 & 7 & 6.7931 & 0.58413 \\
\hline 1260 & 67 & 66 & 66.637 & 1.3464 & 8 & 8 & 7.6423 & 0.65714 \\
\hline 1400 & 72 & 71 & 74.042 & 1.496 & 8 & 9 & 8.4914 & 0.73016 \\
\hline 1540 & 79 & 78 & 81.446 & 1.6456 & 9 & 9 & 9.3405 & 0.80317 \\
\hline 1680 & 86 & 89 & 88.85 & 1.7952 & 10 & 10 & 10.19 & 0.87619 \\
\hline 1820 & 95 & 92 & 96.254 & 1.9448 & 11 & 11 & 11.039 & 0.9492 \\
\hline 1960 & 101 & 103 & 103.66 & 2.0943 & 12 & 12 & 11.888 & 1.0222 \\
\hline
\end{tabular}

Numerical modal analysis: Numerical modal analysis is used to determine the natural frequencies of the machine tool bed. The bed is fixed at the bottom using bolts and they are modeled as fixed supports. The numbers of modes are specified. The modal analysis results are shown in Fig. 9 and comparison of experimental and numerical values are shown in Table 4.

\section{RESULTS}

The comparison of numerical and experimental modal tests prove that natural frequencies of hybrid welded steel bed is higher limiting the probability of resonance as shown in Fig. 11. The damping ratio of the hybrid welded steel bed was 3.5 times that of cast iron as shown in Fig. 12. The comparison of numerical deformation values as shown in Table 5 and the graphical representation in experimental and numerical values are shown in Table 4.

\section{DISCUSSION}

Numerical static analysis: The static analysis requires loads acting on different parts of the machine tool. Due to experimental constraints, the load is applied at the area assuming that the carriage is near tailstock as shown in Fig. 8. The strain and total deformation plot $140 \mathrm{~N}$ is as shown in Fig. 10. The strain and deformation values are tabulated as shown in Table 5 .

Fig. 13 shows that the deformation in welded steel bed is very low compared to cast iron which implies an increase in stiffness of the machine tool bed. The comparison of numerical and experimental strain values of cast iron and hybrid welded steel as shown in Table 5 and Fig. 14 shows that the latter has lesser strain and hence improved static performance.

\section{CONCLUSION}

In this study an attempt has been made to replace cast iron as a lathe bed material with a hybrid bed made of welded steel and polymer concrete core thereby improving the static and dynamic performances of the lathe bed. Numerical modal and static analyses are conducted on the CAD model of the lathe beds. Experimental modal and static analyses are conducted on the fabricated models of the lathe beds to determine natural frequencies, damping ratios and strain respectively. The comparison of numerical and experimental values is compared using graphs and was found to match with each other. The comparison was also made between the values of strain and natural frequencies of cast iron and hybrid welded steel bed which proved the superiority of hybrid welded steel over cast iron. The tests confirm the suitability of welded steel bed as a suitable replacement to cast iron as a material for machine tool structures.

\section{REFERENCES}

Acherkan, N., N. Ignatyev, Y. Mikheyev and V. Khomyakove, 2000. Machine Tool Design. Volume 4 Mir Publications, Moscow. pp: 496. 3, ISBN:0898750490

Corte's, F. and G. Castillo, 2007. Comparison between the dynamical properties of polymer concrete and grey cast iron for machine tool applications", Material. Design,28, ,pp.1461-1466,doi:10.1016/ j.matdes 2006.03.012 
Kim, H.S., K.Y. Park and D.G. Lee, 1995. A study on the epoxy resin concrete for the ultra-precision machine tool bed. J. Mat. Proc. Tech., 48, 1995, pp: 649-655. DOI:10.1016/0924-0136(94)01705-6

Suh, J.D. and D.G. Lee, 2008. Design and manufacture of hybrid polymer concrete bed for high speed CNC milling machine. Int. J. Mech. Mat. Design, 4: 113-121, doi: 10.1007/s10999-0079033-3

Kalpakjian, S. and S.R. Schmid, 2009. Manufacturing Engineering and Technology. 4th Edn., Pearson Education, Inc., pp: 1157. ISBN: 978-81-7758170-6,2009

Rahman, M. and M.A. Mansur, 1990. Development and evaluation of ferrocement legs of a lathe. Int. J. Mach. Tool. Manuf., 30: 629-636. DOI:10.1016/0890-6955(90)90012-8

Rahman, M., M.A. Mansur and K.H. Chua, 1993. Evaluation of a lathe with ferrocement bed. CIRP Annals-Manuf. Technol., 42: 437-440. DOI: 10.1016/S0007-8506(07)62480-9

Rahman, M., M.D. Abul, Mansur and M.D.K., 2001. Bazul, Non-conventional materials for machine tool structures. Int. J. JSME., 44: 1-11, DOI: 10.1299/jsmec.44.1
Orak, S., 2000. Investigation of vibration damping on polymer concrete with polyester resin. Ceme. Conc. Resea., 30: 171-174. DOI: 10.1016/S00088846(99)00225-2

Shevchuk, S.A., 2008. Cast iron in machine tools. Russian. $\quad$ Eng. $\quad$ Rese., 28: 901-903. DOI: 10.3103/S1068798X08090153

Rao, S.S., 2009. Mechanical Vibrations. 4th Edn., Pearson Education, pp: 1104.ISBN: 13:9780132128193

Suh, J.D., D.G. Lee and R. Kegg, 2002. Composite machine tool structures for high speed milling machines,” CIRP Annals - Manuf. Technol., 51: 285-288. DOI: 10.1016/S0007-8506(07)61518-2

Abuthakeer, S.S., G. Mohankumar and P.V. Mohanram, 2010. Prediction and control of cutting tool vibration in CNC lathe with ANN. Nat. J. Technol., 6: 74-86. ISSN-0973-1334

Lan, T.S., 2010. Parametric deduction optimization for surface roughness. Am. J. Applied Sci., 7: 12481253. ISSN 1546-9239

Ping, X. and Y. Ying-hua, 2008. Research on steelfibber polymer concrete machine tool structure. J. Coal Sci. Engin., 14: 689-692.

DOI: 10.1007/s12404-008-0444-z 